IOS Press

\title{
Erratum
}

\section{Erratum to: Quality of teaching in Kosovo's higher education institutions: Viewpoints of institutional leaders and lecturers}

Dugagjin Sokoli, Nada Trunk Širca and Andrej Koren

[Human Systems Management, 40(5) (2021), 685-700, DOI 10.3233/HSM-201155]

https://content.iospress.com/articles/human-systems-management/hsm201155

In the print version of the article, the affiliation of the second author is not complete. The correct affiliations of all authors are:

Dugagjin Sokoli ${ }^{\mathrm{a}}$, Nada Trunk Širca ${ }^{\mathrm{b}, \mathrm{c}}$ and Andrej Koren ${ }^{\mathrm{b}}$

${ }^{a}$ University of Business and Technology, Prishtina, Kosovo

${ }^{\mathrm{b}}$ International School for Social and Business Studies, Celje, Slovenia

${ }^{\mathrm{c}}$ University of Primorska, Koper, Slovenia

This has been corrected in the online files. 